\title{
The Story of 13 Moons: Developing an Environmental Health and Sustainability Curriculum Founded on Indigenous First Foods and Technologies
}

\author{
Jamie Donatuto ${ }^{1, *(D)}$, Larry Campbell ${ }^{1}$, Joyce K. LeCompte ${ }^{2}$, Diana Rohlman ${ }^{3}$ and \\ Sonni Tadlock ${ }^{4}$ \\ 1 Swinomish Community Environmental Health Program, Swinomish Indian Tribal Community, La Conner, \\ WA 98257, USA; lcampbell@swinomish.nsn.us \\ 2 Camassia Resource Stewardship, Rochester, WA 98579, USA; joyceklecompte@gmail.com \\ 3 College of Public Health and Human Sciences, Oregon State University, Corvallis, OR 97331, USA; \\ diana.rohlman@oregonstate.edu \\ 4 Washington SeaGrant, Seattle, WA 98105, USA; sonnit@uw.edu \\ * Correspondence: jdonatuto@swinomish.nsn.us
}

Received: 24 September 2020; Accepted: 22 October 2020; Published: 27 October 2020

check for updates

\begin{abstract}
The Swinomish Indian Tribal Community developed an informal environmental health and sustainability (EHS) curriculum based on Swinomish beliefs and practices. EHS programs developed and implemented by Indigenous communities are extremely scarce. The mainstream view of EHS does not do justice to how many Indigenous peoples define EHS as reciprocal relationships between people, nonhuman beings, homelands, air, and waters. The curriculum provides an alternative informal educational platform for teaching science, technology, engineering, art, and mathematics (STEAM) using identification, harvest, and preparation activities of First Foods and medicines that are important to community members in order to increase awareness and understanding of local EHS issues. The curriculum, called 13 Moons, is founded on a set of guiding principles which may be useful for other Indigenous communities seeking to develop their own curricula.
\end{abstract}

Keywords: indigenous; environmental sustainability; environmental awareness; free-choice learning; informal learning

\section{Introduction}

Our health comes from our culture, and our culture comes from our homelands... We have to take care of Mother Earth because there are uses for just about every bit of or environment. But you have to learn how to use it and you can only do that if you're there, listening. You can't get this from a couch, sitting there watching television.

—wanaseah Larry Campbell, Swinomish Elder

Indigenous peoples are disproportionately impacted by environmental exposures and health disparities [1-3]. The salient impacts are widely recognized within communities and as such are considered high priorities to address [4,5]. Yet a serious disconnect exists between environmental and health agencies and Indigenous communities on how to define and operationalize environmental health and sustainability (EHS). In this paper, and via the stories of Swinomish Elders and leaders, we recount how the Swinomish Indian Tribal Community defines, addresses, and passes on knowledge about environmental health and sustainability.

In the mainstream science paradigm, environmental health $(\mathrm{EH})$ is defined by individual impacts to human health from the food we eat, the water we drink, and the air we breathe [6]. The mainstream 
model is based on risk assessment studies—quantitative exposure assessments of contaminated foods, water, and air via dermal, inhalation, and ingestion pathways to produce probabilities of cancer and non-cancer endpoints. This model, and its subsequent assessment via quantitative probability risk equations, does not do justice to the multi-layered, nuanced, and reciprocal relationships that many Indigenous peoples have with nonhuman living beings, homelands, air, and water [1,7]. Unlike conventional EH, Indigenous knowledge recognizes the essential value of sustainability within education and the environment [8].

While each Indigenous community holds unique worldviews, and thus culturally-specific EHS definitions and priorities, there are some fundamental characteristics that are common across most communities. Indigenous EHS incorporates a combination of practices and knowledge about coexistence with human and nonhuman beings, nature and local natural resources, and spiritual beings, and focuses on familial and community scales, rather than individuals. Indigenous EHS is centered on the importance of culture and tradition, and uses a longer temporal focus that looks both backward in time and forward beyond the present (thus incorporating sustainability).

Concurrently, there are few programs that embrace Indigenous views of EHS. In conventional EHS programs, the primary educational topic (i.e., biology, chemistry, engineering), is commonly taught separately from language and culture. Consider the conventional representation of an ecosystem, which depicts a water-based or land-based food web, absent of humans [9]. In contrast, Indigenous ways of knowing recognize the interconnectedness of all living things (including humans) residing in a given ecosystem $[7,9,10]$. Some advances have been made in developing context-specific EH programming for a handful of Indigenous communities (i.e., lessons on air quality, non-point source pollution, or water quality in a specific geographic region). Yet these curricula typically eschew the broader and more encompassing Indigenous EHS views, such as familial or community-level impacts, nor do they acknowledge the reciprocal relationships that are the foundation of Indigenous EHS [11-13]. EHS education regarding fish advisories is a widely-cited example, wherein rivers or lakes are closed to fishing due to contaminated waters, and posted signs are used to advise would-be fishers to not fish, to eat substitution species, or to stay away from the area for the indefinite future. These fish advisories ignore and go against Indigenous EHS values and practices about human-fish-water relationships [14,15]. Citing one Swinomish elder:

We take care of the fish and the water and they take care of us. We will continue to have ceremonies with fish even if they are contaminated. Like we say, it's our spiritual food so it feeds our soul; so it might poison our body, but then we'd rather nourish our soul [16].

To illustrate why conventional EHS education and intervention practices such as fish consumption advisories fail, we will talk about our experiences as staff and community members of the Swinomish Indian Tribal Community. The Swinomish Indian Tribal Community (Swinomish) is a federally recognized Indian Tribe organized under Section 16 of the Indian Reorganization Act. Today there are nearly 1000 enrolled members. The Swinomish Reservation is located on the southeastern end of Fidalgo Island in Washington State, USA. The Reservation was established by Article 2 of the Point Elliott Treaty between the federal government and Puget Sound Coast Salish communities in 1855. The current Reservation includes approximately 10,800 acres of upland area and approximately 4500 acres of wet and filled tidelands; most of the Reservation is ringed by saltwater (Figure 1). The Swinomish have been a hunting, fishing, and gathering people since time immemorial. Harvesting, preparing, and using First Foods, medicines, and resources (also called traditional foods, or "our foods" by community members) is an integral part of the social and cultural fabric in the Swinomish community.

Figure 2 illustrates the Swinomish definition of EHS. The image depicts 6 key aspects of Swinomish EHS (called Indigenous Health Indicators) in a scene where families are working together beach seining (fishing with nets from the beach), steaming shellfish in a fire pit, and crab fishing. Here, elders can be seen telling stories to Swinomish youth. Younger generations are exploring the beach and surrounding area, and learning how to harvest, cook, and preserve the catch. This image shows Swinomish people 
asserting their sovereignty by being on the land and water and engaging with natural resources that are abundant and accessible. In sum, the image depicts Swinomish people engaging in culturally important practices, which 'feed the body and the spirit' in the Swinomish way [17,18]. This clearly reflects the central importance of First Foods to Swinomish health and wellbeing broadly, and EHS specifically. First Foods can be thought of as cultural keystone species-foods that nourish the body and the spirit of both the individual and the community, while providing opportunities to pass on Indigenous knowledge about connections with nonhuman beings and the environment to the next generations [19]. Therefore, an Indigenous EHS education program taught through the lens of First Foods is a logical and natural coupling.

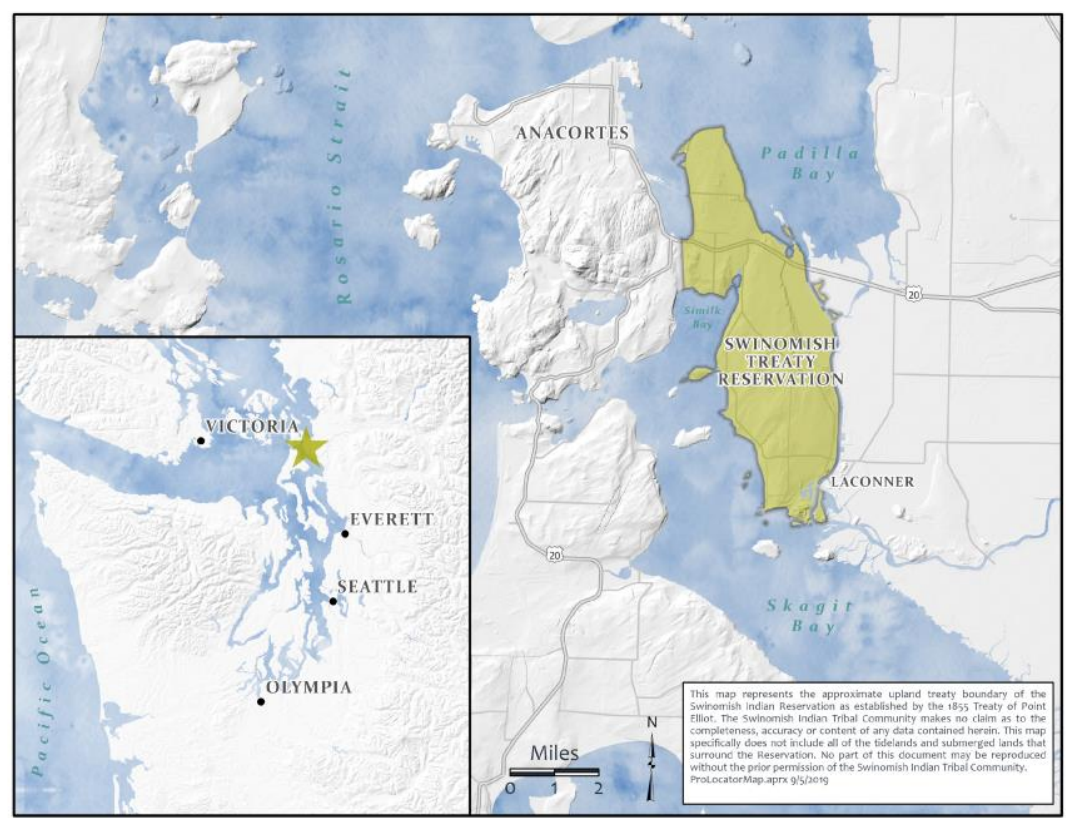

Figure 1. Location of the Swinomish Indian Tribal Community in Washington State, USA.

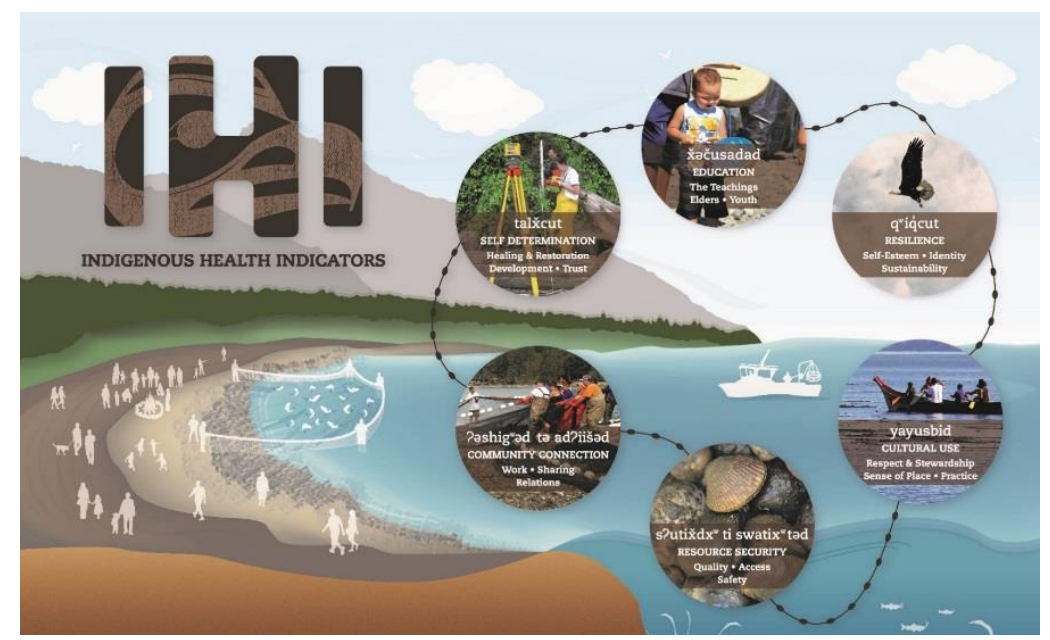

Figure 2. Swinomish Indigenous Health Indicators (IHIs) This image depicts traditional beach seining, overlaid by the Indigenous Health Indicators (listed in Lushootseed and English). Image credit: Emma Fox, Swinomish Communications Department.

In the remainder of this paper, we describe the development of an EHS education curriculum based on Swinomish beliefs and practices around First Foods. The curriculum objectives are to: increase awareness and understanding of local EHS issues among all ages of Swinomish community members; provide an informal (outside of school) educational platform for teaching science, technology, 
engineering, art, and mathematics (STEAM); and increase interest in healthy lifestyles and practices. We developed a set of guiding principles for the curriculum, which may be useful for other Indigenous communities wishing to develop their own curricula.

\section{Materials and Methods}

Our multi-generational curriculum development and implementation team consisted of Swinomish staff members, a Swinomish elder, a Northwest Indian College student, an EH researcher from Oregon State University, and a First Foods expert. In addition, an external advisory group of Indigenous EHS, education, and foods experts provided oversight and review of the draft curriculum. We founded the curriculum on existing Swinomish cultural frameworks, community structures, and existing community knowledge [20], to ensure lesson plans and learning methods are culturally appropriate [10,21-25].

To identify existing Indigenous EHS resources, we evaluated peer-reviewed literature, grey literature, conference proceedings, and personal recommendations. Search terms included the following: Indigenous/Tribal/Native education plus environmental, environmental health, food, nutrition, or First Foods; Indigenous curricula/curriculum; Indigenous K-12 and/or education; and traditional/First Foods curriculum/education. We used the following criteria for inclusion in the list: the resource must describe a curriculum (formal or informal), exhibit, or program (science camp, museum exhibit); the resource must be specific to Indigenous populations; and resources are specific to North America.

A thematic analysis identified guiding principles. The analysis included recommendations from culturally based science education $[21-23,26,27]$, review of research and curriculum implementation notes, insights from our collated resources, and input from Tribal elders. The project team agreed on eight guiding principles, which formed the curriculum framework for developing activities.

We used an asset-based approach and free-choice learning methods to develop the curriculum. Asset-based approaches to education are more successful than deficit-based approaches as they recognize cultural knowledge sources and community strengths $[28,29]$. Culturally based education promotes the inclusion of cultural assets, such as native languages, traditional and cultural practices, and community-based oral history and ways of knowing $[10,26]$. The focus on these assets changes the orientation of the educational program from a Western perspective to an Indigenous perspective [29,30]. Free-choice learning is self-motivated learning taking place outside of a formal classroom setting. When developed and implemented through a culturally based approach, free-choice science learning outside the school system resonates with how Indigenous communities have been passing on knowledge about their environments for millennia.

The curriculum underwent multiple iterations of evaluation: internal review; Swinomish community review; external review with the advisory committee of Indigenous EHS, education and foods experts, an independent Indigenous evaluation team; and review by the Swinomish Health, Education and Social Services Committee prior to publication. Working with an independent Indigenous evaluation team, we identified and incorporated the following outcomes into the overall evaluation. The 13 Moons program was designed to increase: opportunities for informal EHS learning through a cultural lens; awareness and understanding of EHS in the Swinomish community; understanding of a healthy community that encompasses physical, mental, spiritual, and environmental health; interest or motivation to implement healthy lifestyles, traditional practices, and harvesting; youth interest and engagement with elders, traditional practices; and youth interest in STEAM fields and careers.

\section{Results}

We identified 60 curricula and resources (Figure 3). The curricula are predominantly subject-specific. For example, the Air Toxics under the North Star [12] curriculum focuses on indoor air. There were several environmental curricula [11,31,32]. A full list is available (see Appendix A). Taken together, all resources fall under the umbrella of EHS, albeit to varying degrees. We did not 
identify curricula that provided a comprehensive Indigenous EHS overview of the complex interplay between humans, nonhuman beings, and their environments.

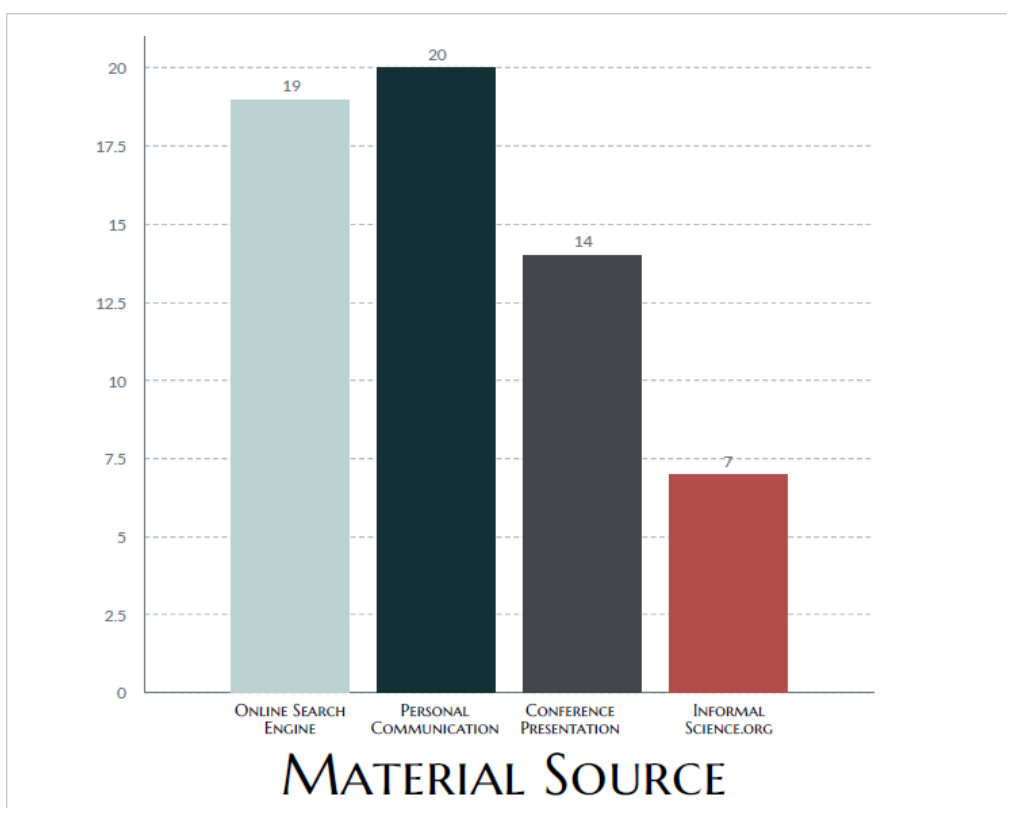

(a)

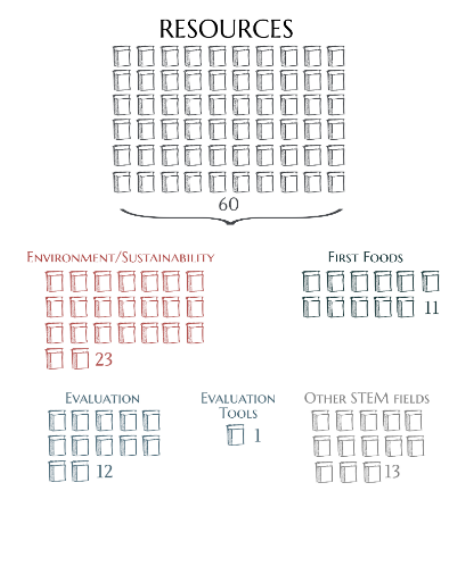

(b)

Figure 3. Description of curricula and resources related to environmental health. (a) Materials were sourced from online searches, personal communication, conference presentations, and InformalScience.org. Limited materials were found via traditional peer-reviewed publications. (b) 60 materials were identified relative to environmental health $(\mathrm{EH})$.

The eight guiding principles (Figure 4) are reflected in each activity of the 13 Moons curriculum. While based on Swinomish beliefs, values, and practices, the principles are designed as an adaptable framework for other Indigenous communities. These principles are meant to help develop activities around a community's own set of culturally important First Foods, medicines, and technologies.

We named the curriculum "13 Moons," which signifies the traditional Swinomish harvest calendar. Each moon is named for an important seasonal event or harvest that takes place during that moon [33]. We designed 2-3 activities per moon that utilize a plant and an animal species (Table 1). The curriculum is designed to encourage scaffolding of knowledge; students will learn about ironwood in the spring, and then use ironwood tools to weave cattail mats in the early autumn, which are then used during community dinners during the winter season. This continuity speaks to the repetition and integration built into 13 Moons. Each activity includes a complete lesson plan which includes: background on the food, medicine, or technology; learning objectives; time to complete the activity; target age group (activities are designed to span from pre-Kindergarten to elders); materials needed; words to learn in the Swinomish language (Lushootseed), knowledge transfer goals (from elders to youth); guiding questions for discussion; identification of environmental health connections; optional additional activities; and a citation and resource list. In the four years since we began in 2016, we have piloted many, but not all, of the activities. Figure 5 depicts an activity from the curriculum to illustrate the objectives, content, and format we use.

Late December though early January is Moon of the Sacred Time. Both the final moon of one yearly cycle and the beginning moon of the next cycle, the Moon of the Sacred Time is a time for renewal and rebirth. This is a time for learning spiritual and cultural traditions from Elders around the longhouse fire. Sea-run cutthroat trout, blackmouth salmon, and steelhead are fished during the winter months. Shellfish are collected during the night-time low tides. (Text from the 13 Moons curriculum) 

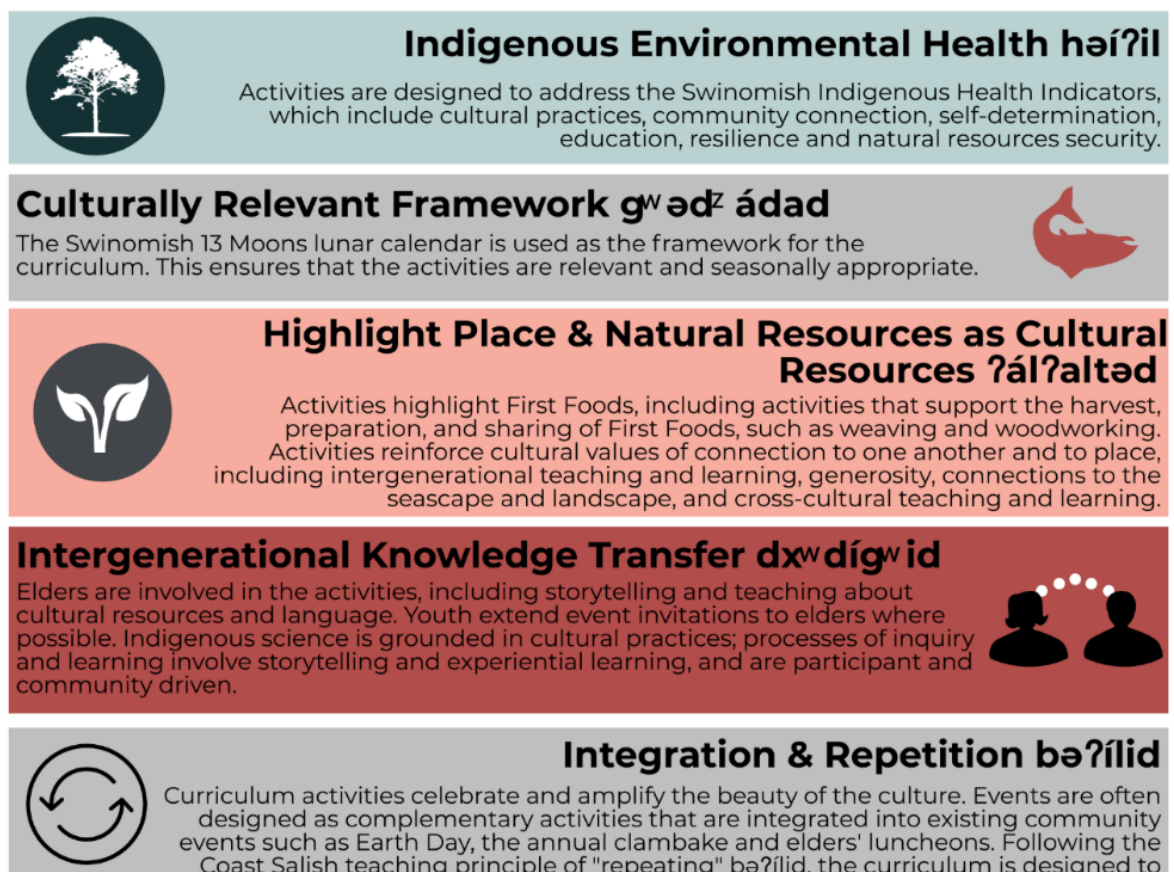

Integration \& Repetition bə?ílid

Curriculum activities celebrate and amplify the beauty of the culture. Events are often designed as complementary activities that are integrated into existing community events such as Earth Day, the annual clambake and elders' luncheons. Following the Coast Salish teaching principle of "repeating" ba?ílid, the curriculum is designed to reinforce knowledge through repetition with the seasonal round from year to year, revisiting places, plants, and animals at different phases of the Swinomish lunar calendar. Many activities are designed to provide opportunities for older youth to "repeat" the teaching to younger ones.

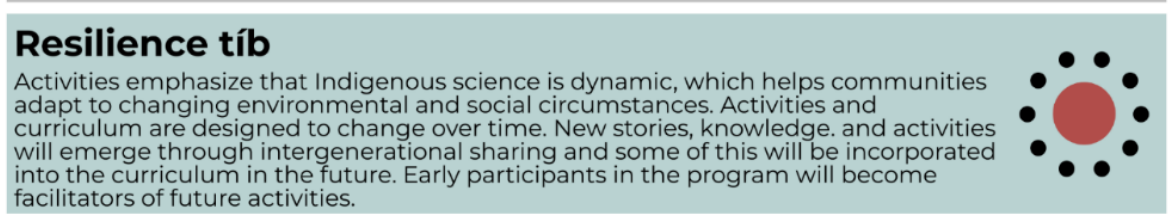
facilitators of future activities.

\section{tígwicid}

Honoring the Language dxwləšúcid

\section{Adaptable Module Design d Wo:X}

A modular activities design accommodates differences in scheduling, age, knowledge and abilities.

Figure 4. The eight Guiding Principles forming the foundation of the 13 Moons environmental sustainability and health curriculum. While the majority of the activities within the 13 Moons curriculum are Swinomish or Coast Salish specific, the overarching framework and guiding principles of the curriculum are designed to be tailored to specific seasons, resources, and harvest cycles of other Indigenous communities. The Lushootseed translation is included for each guiding principle.

Table 1. The 13 Moons seasonal activity calendar. Each moon is named for an important seasonal event or harvest that takes place during that moon and contains 2-3 activities.

\begin{tabular}{|c|c|c|c|c|c|}
\hline Moon & $\begin{array}{l}\text { Natural } \\
\text { Resources } \\
\text { Focus }\end{array}$ & $\begin{array}{l}\text { Connection to } \mathrm{EH} \text { and } \\
\text { Sustainability }\end{array}$ & $\begin{array}{l}\text { Description of } \\
\text { Selected Activities }\end{array}$ & $\begin{array}{c}\text { Concepts or Principles } \\
\text { Addressed }\end{array}$ & $\begin{array}{l}\text { Skills Learned } \\
\text { or Gained * }\end{array}$ \\
\hline Windy Time & $\begin{array}{l}\text { Observational } \\
\text { learning }\end{array}$ & $\begin{array}{l}\text { Introduction to Environmental } \\
\text { Sciences and Indigenous } \\
\text { scientific methods of } \\
\text { observation over time }\end{array}$ & $\begin{array}{c}\text { Local } \\
\text { Environmental } \\
\text { Observer network }\end{array}$ & $\begin{array}{l}\text { Spatial visualization of data } \\
\text { (mapping) }\end{array}$ & $1-3$ \\
\hline Frog Talks & $\begin{array}{l}\text { Spring Greens; } \\
\text { Herring }\end{array}$ & $\begin{array}{l}\text { Habitat and ecological } \\
\text { relationships/Food web } \\
\text { interactions }\end{array}$ & $\begin{array}{l}\text { Spring greens } \\
\text { harvest }\end{array}$ & $\begin{array}{l}\text { Species-habitat } \\
\text { relationships; predator/prey } \\
\text { relationships; numeracy }\end{array}$ & $4-6$ \\
\hline $\begin{array}{l}\text { Whistling } \\
\text { Robins }\end{array}$ & $\begin{array}{l}\text { Ironwood; } \\
\text { Water }\end{array}$ & $\begin{array}{c}\text { Water quality (WQ); } \\
\text { Environmental Sustainability }\end{array}$ & $\begin{array}{l}\text { Ironwood tools; } \\
\text { Earth Day activities }\end{array}$ & $\begin{array}{l}\text { Conservation of natural } \\
\text { resources; technology in tool } \\
\text { making }\end{array}$ & $6-9$ \\
\hline
\end{tabular}


Table 1. Cont.

\begin{tabular}{|c|c|c|c|c|c|}
\hline Moon & $\begin{array}{l}\text { Natural } \\
\text { Resources } \\
\text { Focus }\end{array}$ & $\begin{array}{l}\text { Connection to EH and } \\
\text { Sustainability }\end{array}$ & $\begin{array}{l}\text { Description of } \\
\text { Selected Activities }\end{array}$ & $\begin{array}{l}\text { Concepts or Principles } \\
\text { Addressed }\end{array}$ & $\begin{array}{l}\text { Skills Learned } \\
\text { or Gained * }\end{array}$ \\
\hline Digging Time & $\begin{array}{l}\text { Camas; } \\
\text { Bentwood Box } \\
\text { Traditional } \\
\text { Coast Salish } \\
\text { Foods and } \\
\text { Tools }\end{array}$ & $\begin{array}{l}\text { Sustainable agriculture; } \\
\text { conservation of natural } \\
\text { resources; phenology }\end{array}$ & $\begin{array}{l}\text { Harvest, prepare } \\
\text { camas; Blessing of } \\
\text { the Fleet }\end{array}$ & $\begin{array}{l}\text { Use of fire to manage } \\
\text { ecosystems; technology in } \\
\text { tool making; phenology }\end{array}$ & $6-10$ \\
\hline Salmon-berry & $\begin{array}{l}\text { Native } \\
\text { berries/plants; } \\
\text { Shellfish }\end{array}$ & $\begin{array}{l}\text { Habitat and ecological } \\
\text { relationships/Food web } \\
\text { interactions/coupled } \\
\text { socio-ecological systems; } \\
\text { phenology }\end{array}$ & $\begin{array}{l}\text { Salmonberry Soda; } \\
\text { Clam shell dig }\end{array}$ & $\begin{array}{l}\text { Conservation of natural } \\
\text { resources; phenology }\end{array}$ & $6-11$ \\
\hline Blackberry & Berries; Salmon & $\begin{array}{l}\text { Habitat and ecological } \\
\text { relationships/Food web } \\
\text { interactions/coupled } \\
\text { socio-ecological systems; } \\
\text { phenology }\end{array}$ & $\begin{array}{l}\text { Jam workshop; } \\
\text { Beach seining }\end{array}$ & $\begin{array}{l}\text { Conservation of natural } \\
\text { resources; technology in tool } \\
\text { making; phenology }\end{array}$ & $6-11$ \\
\hline Salal & $\begin{array}{c}\text { Marine } \\
\text { invertebrates }\end{array}$ & $\begin{array}{l}\text { WQ; coupled socio-ecological } \\
\text { systems }\end{array}$ & $\begin{array}{l}\text { Clam bake; } \\
\text { Invertebrate } \\
\text { survey; build water } \\
\text { filters }\end{array}$ & $\begin{array}{l}\text { Careers in environmental } \\
\text { science; WQ and sampling } \\
\text { methods }\end{array}$ & $12-15$ \\
\hline Silver Salmon & Berries; Seeds & $\begin{array}{l}\text { Sustainable agriculture; } \\
\text { Phenology }\end{array}$ & $\begin{array}{l}\text { Seed saving \& food } \\
\text { preservation } \\
\text { workshops }\end{array}$ & $\begin{array}{c}\text { Environmental } \\
\text { sustainability; phenology }\end{array}$ & $4,6,8$ \\
\hline Elk Mating Cry & $\begin{array}{l}\text { Riparian plants; } \\
\text { Salmon; elk }\end{array}$ & $\begin{array}{l}\text { Habitat and ecological } \\
\text { relationships/Food web } \\
\text { interactions; WQ }\end{array}$ & $\begin{array}{l}\text { Stream field trip, } \\
\text { salmon habitat }\end{array}$ & $\begin{array}{c}\text { Ecology; fisheries and } \\
\text { wildlife; environmental } \\
\text { sustainability }\end{array}$ & $4,9,14$ \\
\hline Falling Leaves & $\begin{array}{l}\text { Cattail; Elk \& } \\
\text { deer }\end{array}$ & Climate change; Phenology & $\begin{array}{c}\text { Cattail matt } \\
\text { workshop; } \\
\text { Pemmican class }\end{array}$ & $\begin{array}{c}\text { Weather } \\
\text { systems/meteorology; } \\
\text { technology in tool making; } \\
\text { phenology }\end{array}$ & $2-3,14,16$ \\
\hline Dog Salmon & Bentwood Box & $\begin{array}{l}\text { Sustainable agriculture; } \\
\text { conservation of natural } \\
\text { resources; phenology }\end{array}$ & $\begin{array}{l}\text { Traditional foods } \\
\text { and resources } \\
\text { preservation } \\
\text { methods }\end{array}$ & $\begin{array}{c}\text { Sustainability technologies } \\
\text { in food preservation; asking } \\
\text { questions }\end{array}$ & 4,11 \\
\hline $\begin{array}{c}\text { Put Your } \\
\text { Paddles Away }\end{array}$ & Conifers & $\begin{array}{l}\text { Environmental literacy; } \\
\text { phenology }\end{array}$ & $\begin{array}{l}\text { Medicine of the } \\
\text { Trees workshop }\end{array}$ & $\begin{array}{l}\text { Conservation of natural } \\
\text { resources; technology in tool } \\
\text { making; phenology; } \\
\text { numeracy }\end{array}$ & $5-6,8$ \\
\hline Sacred Time & Cedar; Clams & $\begin{array}{l}\text { WQ; coupled socio-ecological } \\
\text { systems }\end{array}$ & $\begin{array}{l}\text { Night-time clam } \\
\text { dig }\end{array}$ & $\begin{array}{l}\text { Careers in environmental } \\
\text { science; WQ and sampling } \\
\text { methods }\end{array}$ & $12-13,17$ \\
\hline
\end{tabular}

* Notes: ${ }^{1}$ Scientific Practice. ${ }^{2}$ Record environmental/scientific observations. ${ }^{3}$ Mapping. ${ }^{4}$ Increased understanding of ecological relationships. ${ }^{5}$ Weight and volume measurements/conversions. ${ }^{6}$ Beneficial impact of humans on the ecosystem. ${ }^{7}$ Environmental sustainability practices. ${ }^{8}$ Proper harvest/care of environmentally important plants. ${ }^{9}$ Active learning. ${ }^{10}$ Presentation skills. ${ }^{11}$ Food Safety. ${ }^{12}$ Increasing understanding of water quality. ${ }^{13}$ Methods for scientific/environmental testing/monitoring. ${ }^{14}$ Deductive reasoning skills. ${ }^{15}$ Problem solving skills. ${ }^{16}$ Correlating weather patterns to animal migration/invasive plant species. ${ }^{17}$ Data-driven decision making.

An external Indigenous evaluation team reviewed the curriculum based on stated project outcomes. Overall, participant feedback indicated that the program is successful [34]. The evaluation identified several foundational strategies that contributed to success, namely: the program built off existing activities (e.g., annual celebrations, Swinomish youth program, Earth day, community dinners); Swinomish community members and elders were involved in the design and implementation of activities; and community assets and resources were the focus of all activities. Swinomish community members supported the program, as they felt it sustained healthy cultural practices, promoted intergenerational learning, and increased community connection. As one community member explained, the 13 Moons activities created a place and space for learning: "People started to speak out about what they were taught; so I think that it's bringing knowledge together, it's bringing teachings, and it's bringing community thoughts together on what they were told, on what their grandparents told them." Another community member noted, "As a Native people, we eat together, we gather together, it's that sense of learning together that brings a traditional aspect... it's a familiar setting for me" [34]. 

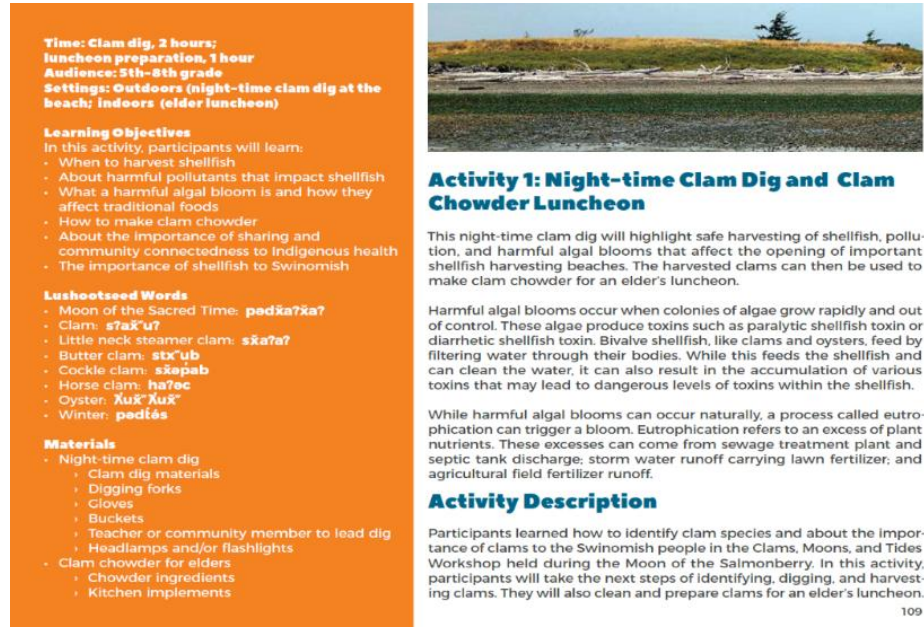

Activity 1: Night-time Clam Dig and Clam Chowder Luncheon

This night-time clam dig will highlight safe harvesting of shellfish, pollu
tion tion. and harmful algal blooms that affect the opening of important
sheilifish harvesting beaches . The harvested clams can then be used to
make clam chowder for Harmful algal blooms occur when colonies of algae grow rapidily and out
of control These algoe of control. These algae produce toxins such as paralytic shellffish toxin or
diarrthetic shellfísh toxin. Bivalive shellfifhh like clarms and oysters, feed b by filarhing water through theil bodies. While this feeds the shenefifish and
can clean the water, it can also result in the accumulation of various can clean the water, it can also result in the accumulation of various
toxins that may lead to dangerous levels of toxins within the shellifish.

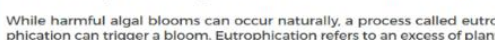

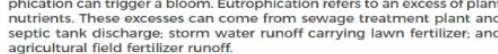

Activity Description Participants learned how to identify clam species and about the impor
tanceof clams to the Swininomisth peopole in the clams. Moons. and Tides
Workshop held during the Moon of the Salmonberry. In this activity Workshop held during the Moon of the Salmonberry. In this activity
participants will take the next steps of identifying, digging, and harvest
ing clarns. They will also clean and prepare clams for an elder's luncheorn

(a)

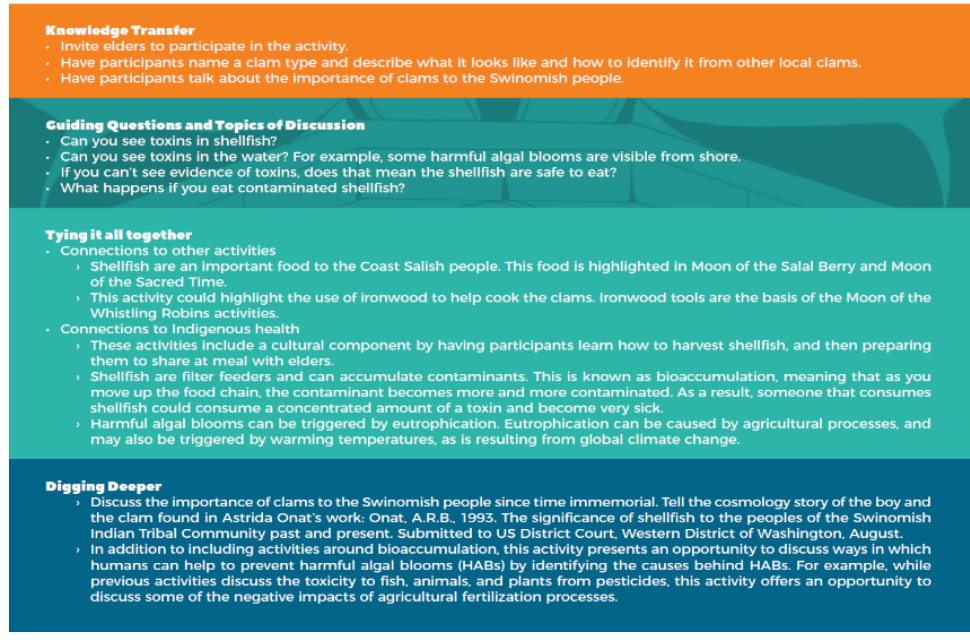

(b)

Figure 5. These panels depict a 13 Moons activity about a clam dig, demonstrating the content, style, and layout of the 13 Moons curriculum. (a) The first panel includes information on: time, audience, setting, learning objectives, Lushootseed words, materials, and activity description. (b) The second panel contains descriptions of: knowledge transfer; guiding questions and topics of discussion; trying it all together; and, digging deeper.

\section{Discussion}

We designed the Swinomish 13 Moons curriculum to overcome environmental, cultural, and literacy barriers in EHS programming [10,35-39]. We found the approach successful within the Swinomish community, with the most common feedback being requests for more activities. The local school district has requested use of the curriculum, and other Indigenous communities have expressed interest in tailoring the curriculum for their own use. Due to the seasonality of the program, not all proposed activities could be completed in the three-year pilot phase. Future work will evaluate the success of the entire 13 Moons curriculum.

A review of published guidelines indicates that culturally based education (CBE) should situate learning within the community and cultural framework, build the curriculum on a foundation of cultural practices, and value Indigenous knowledge alongside conventional knowledge $[10,21-23,26,27,40]$. Specifically, Demmert and Towner (2003) published five CBE guidelines: (i) Culturally based indigenous language use; (ii) culturally based pedagogy; (iii) culturally based curriculum; (iv) culturally based patterns of participation in leadership and decision making and; (v) culturally based methods of 
assessing student performance [26,27]. In 13 Moons, the Lushootseed language is integrated into each activity and each activity is led or introduced by Swinomish elders and knowledge-keepers (elements i and iv). A culturally based pedagogy (element ii) is defined as one "that empowers students intellectually, socially, emotionally and politically using cultural references to impart knowledge, skills and attitudes" [41]. As such, culturally based pedagogy views success in the long term, focuses on cultural competency within the learner's own culture, and highlights the socio-cultural framework of their community [42,43]. With First Foods and the lunar cycle as a foundation (element iii), as well as place-based activities, the curriculum explains Swinomish history, traditions, and culture; success is not measured quantitatively but qualitatively as students combine their knowledge and work with elders and instructors to complete activities. Finally, we used Indigenous evaluation methodologies (element $\mathrm{v})$. This approach allows a holistic evaluation of participant engagement, knowledge transfer, and satisfaction with the program. While the curriculum is Swinomish specific, other Indigenous communities may find success in EHS engagement via the eight guiding principles and tailoring the First Foods, medicines, and technologies activities to their own values and practices.

\section{Conclusions}

The Swinomish 13 Moons program was developed in response to a paucity of Indigenous environmental health and sustainability educational programs. Our program welcomes learners of all ages in an informal learning environment and highlights Swinomish culture, traditions, and concepts at the forefront. We grounded the entire curriculum in principles of culturally based education and identified additional guiding principles that represent Swinomish principles of teaching, resilience, and sustainability. The curriculum was developed by Swinomish, for Swinomish. In addition, we created the guiding principles as our own foundation, and we hope that they will help other Indigenous communities in their journeys to revitalize culture and language as foundations in their curricula. The concept of the seasonal round is shared by many Indigenous communities, and the focus on First Foods ensures that the content is culturally relevant. The adaptable module design also encourages Western educational programs to incorporate elements into formal or informal programs. Thus, the 13 Moons program demonstrates a highly relevant, culturally-based education program for learners of all ages that can be adapted by Indigenous communities throughout North America.

In closing, we share with you a quote that exemplifies how environmental health and sustainability is one integrated concept, from the Swinomish point of view:

I fostered two teenagers... They were getting into a little bit of trouble. They wore the backwards hats and they got the Native pride, you know, "I'm Indian, I'm Indian." I said, "Well, you really want to show your people how to be Indian, here I'll show you." I just happened to be filleting fish, I had a lot of fish. And we filleted them and I made them help me ... I said, "... this is how you want to be Indian is you provide food for your people. It's not standing on the corner with a Native pride hat acting tough. That's not Indian." The effect on them was just passing that on ... the importance, and emphasis that we have to gather these foods, we have to provide these foods in the wintertime when we're putting food on the table for the [ceremonial] smokehouse.

-Swinomish tribal member [44].

Author Contributions: Conceptualization, L.C., J.D., J.K.L., and D.R.; methodology, J.D., J.K.L., and D.R.; formal analysis, J.D., J.K.L., and D.R.; resources, L.C., J.D., J.K.L., and S.T.; data curation, J.D. and D.R.; writing-original draft preparation, J.D.; writing - review and editing, J.K.L., D.R., and S.T.; supervision, J.D.; project administration, J.D.; funding acquisition, J.D. and D.R. All authors have read and agreed to the published version of the manuscript.

Funding: This work was supported by: the National Science Foundation under the Advancing Informal STEM Learning Grants DRL-1516742 and DRL-1812543; the US Environmental Protection Agency under the Science to Achieve Results Grant \#83559501; a First Nations Development Institute Grant; and, the Center for Disease Control and Prevention under the Good Health and Wellness award to the Northwest Portland Area Indian Health Board's Wellness for Every American Indian to Achieve and View Health Equity (WEAVE-NW). Any opinions, findings, and conclusions or recommendations expressed here are those of the author(s) and do not necessarily 
reflect the views of the National Science Foundation, the US Environmental Protection Agency, the First Nations Development Institute, the Center for Disease Control and Prevention, the Northwest Portland Area Indian Health Board, nor the Swinomish Indian Tribal Community.

Acknowledgments: Many thanks to the project's team, advisory board, and curriculum reviewers for their insights and expertise. Special acknowledgements to Elise Krohn and Valerie Segrest for their tireless work teaching the wisdoms of First Foods, medicines, and technologies in Coast Salish territories.

Conflicts of Interest: The authors declare no conflict of interest. The funders had no role in the design of the study; in the collection, analyses, or interpretation of data; in the writing of the manuscript, or in the decision to publish the results.

\section{Appendix A}

The full list of curricula and resources reviewed is listed below. Where available, links are provided to the content.

\begin{tabular}{|c|c|c|}
\hline & Program & Citation or URL \\
\hline 1 & 100 Years & $\begin{array}{l}\text { Policy. An exhibit that reflects upon the human experiencebehind } \\
\text { enacted policies and laws on Pueblo communities by other } \\
\text { governments. https://web.archive.org/web/20160115085458/http: } \\
\text { //indianpueblo.org:80/100years/ }\end{array}$ \\
\hline
\end{tabular}

3 Air Toxics under the North Star

http://education.cehs.health.umt.edu/content/air-toxics-undernorth-star

\begin{tabular}{ll}
\hline 4 & Alaska Native Knowledge Network \\
\hline 5 & $\begin{array}{l}\text { Aleutian Pribilof Islands Association } \\
\text { Traditional Foods Program (The Aleut Diet } \\
\text { Program) and Qaqamiigux Curriculum } \\
\text { (preschool) }\end{array}$ \\
\hline 6 & $\begin{array}{l}\text { Building True Capacity: Indigenous Models } \\
\text { for Indigenous Communities }\end{array}$
\end{tabular}

http://ankn.uaf.edu/Curriculum/Units/

http://www.apiai.org/services/community-services/traditional-

foods-program/

https://www.apiai.org/services/education/head-start/qaqamiiguxhead-start-traditional-foods-preschool-curriculum/\#curriculum

Chino, M. and DeBruyn, L. Building true capacity: Indigenous models for indigenous communities. American J. Public Health 2006, $96,596-599$.

7 Canadian Wildlife Federation https://cwf-fcf.org/en/resources/for-educators/?src=menu

8 Cedar Box Teaching Toolkit

This teaching tool was created by Elise Krohn and Valerie Segrest, and is licensed under the Creative Commons

Attribution-NonCommercial-NoDerivatives 4.0 International

License. It is available from the North Portland Area Indian Health Board.

9 Center for Native Peoples and the

Center for Native Peoples and the Environment. ESF SUNY College

of Environmental Science and Forestry.

Environment

https://www.esf.edu/nativepeoples/

\begin{tabular}{|c|c|c|}
\hline 10 & $\begin{array}{l}\text { Center for World Indigenous Scholars|Center } \\
\text { for Traditional Medicine }\end{array}$ & https://www.cwis.org/what-we-do/ \\
\hline 11 & Coastal First Nations Turning Point Initiative & http://www.coastalfirstnations.ca/publications-resources \\
\hline 12 & $\begin{array}{l}\text { Community Dialogues on First Nations } \\
\text { Holistic Lifelong Learning }\end{array}$ & $\begin{array}{l}\text { Canadian Council on Learning. Community Dialogues on First } \\
\text { Nations Holistic Lifelong Learning: Learning as a Community for renewal } \\
\text { and growth. Canadian Council on Learning. Aboriginal Lerning } \\
\text { Knowledge Centre: Ottawa, ON, USA, } 2009\end{array}$ \\
\hline 13 & Cosmic Serpent & $\begin{array}{l}\text { Peticolas, L., Maryboy, N., Begay, D., Stein, J., Valdez, S. and } \\
\text { Paglierani, R., 2012, August. A Place of Transformation: Lessons } \\
\text { from the Cosmic Serpent Informal Science Education Professional } \\
\text { Development Project. In Proceedings of the Connecting People to } \\
\text { Science: A National Conference on Science Education and Public } \\
\text { Outreach, Baltimore, MD, USA, } 30 \text { July-3 August 2012; p. } 321 .\end{array}$ \\
\hline
\end{tabular}




\begin{tabular}{|c|c|c|}
\hline 14 & CRTIFC Salmon Camp & http://www.critfc.org/for-kids-home/salmon-camp/ \\
\hline 15 & $\begin{array}{l}\text { Culturally Competent Evaluation in Indian } \\
\text { Country }\end{array}$ & $\begin{array}{l}\text { LaFrance, J. Culturally competent evaluation in Indian country. } \\
\text { New Directions for Evaluation 2004, 102, pp.39-50. }\end{array}$ \\
\hline 16 & eETHICS & Pearson, C., Parker M., Fisher C. eETHICS \\
\hline 17 & $\begin{array}{l}\text { Effective practices for creating transformative } \\
\text { informal science education programs } \\
\text { grounded in Native ways of knowing }\end{array}$ & $\begin{array}{l}\text { Mack, E., Augare, H., Different Cloud-Jones, L. et al. Cult Stud of Sci } \\
\text { Educ (2012) 7: 49. https://doi.org/10.1007/s11422-011-9374-y }\end{array}$ \\
\hline 18 & $\begin{array}{l}\text { Empowering Ramah Navajos to Eat Healthy } \\
\text { by Using Traditional Foods }\end{array}$ & https://americanindianinstitute.wordpress.com/2012/09/05/rnc/ \\
\hline 19 & $\begin{array}{l}\text { Environmental Education and Indigenous } \\
\text { Knowledge }\end{array}$ & $\begin{array}{l}\text { Monthly webinar series presented by NAAEE. } \\
\text { https://naaee.org/eepro/learning/webinars/webinar-environmental- } \\
\text { education-and }\end{array}$ \\
\hline
\end{tabular}

Environmental Protection Native American

20 Lands: A Cultural Approach to Integrated http://hdl.handle.net/2148/124 Environmental Studies

\begin{tabular}{lll}
\multicolumn{2}{c}{ Environmental Studies } & \\
\hline 21 & $\begin{array}{l}\text { Evaluating Indigenous programs: a toolkit for } \\
\text { change }\end{array}$ & $\begin{array}{l}\text { Hudson, S., Salvatierra, C.A.M. and Andres, C., 2017. Evaluating } \\
\text { Indigenous programs: A toolkit for change. Sydney; Australia, } \\
\text { NSW: Centre for Independent Studies. } \\
\text { https://www.cis.org.au/app/uploads/2017/06/rr28.pdf }\end{array}$ \\
\hline 22 & Fish to Schools & http://www.uaf.edu/canhr/projects/fishschools/ \\
\hline 23 & Fish Wars & http://nmai.si.edu/nk360/pnw-fish-wars/index.cshtml\#title \\
\hline
\end{tabular}

Simonds, V.W., Kim, F.L., LaVeaux, D., Pickett, V., Milakovich, J. and Cummins, J. Guardians of the living water: using a health literacy framework to evaluate a child as change agent intervention. Health Education \& Behavior 2019, 46, 349-359.

24 Guardians of the Living Water Environmental Health Literacy Project

LaVeaux, D., Simonds, V.W., Picket, V., Cummins, J. and Calkins, E., 2018. Developing a Curriculum for Change: Water \& Environmental Health Literacy in a Native American Community. Progress in community health partnerships: research, education, and action, 12(4), p.441.

http://www.ncai.org/policy-research-center/initiatives/MSU_ Guardians_of_Living_Water.pdf

\begin{tabular}{|c|c|c|}
\hline 25 & $\begin{array}{l}\text { Guidelines for Considering Traditional } \\
\text { Knowledges in Climate Change Initiatives }\end{array}$ & https://climatetkw.wordpress.com/resources/ \\
\hline 26 & $\begin{array}{l}\text { Handbook for Culturally Responsive Science } \\
\text { Curriculum }\end{array}$ & http://ankn.uaf.edu/publications/handbook/ \\
\hline 27 & $\begin{array}{l}\text { Healthy Traditions-Confederated Tribes of } \\
\text { Siletz }\end{array}$ & $\begin{array}{l}\text { https://www.facebook.com/Healthy-Traditions-127422657322379/ } \\
\text { info/?tab=page_info }\end{array}$ \\
\hline 28 & Help Yourself to a Healthy Home & $\begin{array}{l}\text { Native American Housing Technical Assistance Institute, Montana } \\
\text { State University Extension, Boseman, Montana. } \\
\text { https://www.epa.gov/sites/production/files/2016-08/documents/ } \\
\text { 2016-08-r9-rtoc-presentation-help-yourself-to-healthy-home.pdf }\end{array}$ \\
\hline 29 & $\begin{array}{l}\text { Impacts of a holistic place-based community } \\
\text { internship on participant interest in science } \\
\text { and conservation pathways }\end{array}$ & $\begin{array}{l}\text { LEMUS, Judith D. Impacts of a holistic place-based community } \\
\text { internship on participant interest in science and conservation } \\
\text { pathways. Journal of STEM Outreach, [S.1.], v. 1, n. 1, jan. 2018. doi: } \\
\text { https://doi.org/10.15695/jstem/v1i1.3 ISSN 2576-6767. }\end{array}$ \\
\hline 30 & $\begin{array}{l}\text { INDIAN EDUCATION Utah State Office of } \\
\text { Education }\end{array}$ & https://www.uen.org/core/socialstudies/americanindian/\#lessons \\
\hline 31 & Indigenous Arts and Science & $\begin{array}{l}\text { University of Wisconsin. } \\
\text { https://earthpartnership.wisc.edu/indigenous-arts-and-sciences/ }\end{array}$ \\
\hline 32 & Indigenous Evaluation Toolkit & $\begin{array}{l}\text { Developed by the Great Plains Tribal Epidemiology Center. } \\
\text { Contains } 13 \text { resources. } \\
\text { https://gptec.gptchb.org/indigenous-evaluation-toolkit/ }\end{array}$ \\
\hline
\end{tabular}




\begin{tabular}{|c|c|c|}
\hline 33 & $\begin{array}{l}\text { Indigenous Knowledge and Environmental } \\
\text { Sustainability }\end{array}$ & $\begin{array}{l}\text { Environmental studies. Indigenous Knowledge and Environmental } \\
\text { Sustainability. University of Montana. } \\
\text { https://hs.umt.edu/evst/graduate/focus-areas/indigenous- } \\
\text { knowledge/default.php }\end{array}$ \\
\hline 34 & $\begin{array}{l}\text { Integrating Indigenous and Western } \\
\text { Knowledge to Transform Learning and } \\
\text { Discovery in the Geosciences }\end{array}$ & http://includes2017.videohall.com/presentations/845 \\
\hline 35 & Inuit Holistic Lifelong Learning Model & $\begin{array}{l}\text { http://katiqsugat.itk.ca/files/original/ } \\
\text { da2d254f708eaf30f4e37ee8e7e8a332.pdf }\end{array}$ \\
\hline 36 & Lessons of our Land & http://www.lessonsofourland.org/lessons/traditional-use-plants \\
\hline 37 & $\begin{array}{l}\text { Living in Health, Harmony and Beauty: The } \\
\text { Dine (Navajo) Hozho wellness philosophy }\end{array}$ & $\begin{array}{l}\text { Kahn-John, M. and Koithan, M., 2015. Living in health, harmony, } \\
\text { and beauty: the dine (navajo) hozho wellness philosophy. Global } \\
\text { advances in health and medicine 2015, 4, 24-30. }\end{array}$ \\
\hline 38 & Living Maya Time & https://maya.nmai.si.edu/ \\
\hline 39 & $\begin{array}{l}\text { Local Environmental Observer (LEO) } \\
\text { network }\end{array}$ & $\begin{array}{l}\text { https://anthc.org/what-we-do/community-environment-and- } \\
\text { health/leo-network/ }\end{array}$ \\
\hline 40 & Metis Holistic Lifelong Learning Model & http://firstnationspedagogy.ca/CCL_Learning_Model_MET.pdf \\
\hline 41 & Mother's Roots & $\begin{array}{l}\text { https://cedar.wwu.edu/cgi/viewcontent.cgi?article=1569\&context= } \\
\text { wwuet }\end{array}$ \\
\hline 42 & Native Knowledge 360 & https://americanindian.si.edu/nk360 \\
\hline 43 & Native Science Field Center & $\begin{array}{l}\text { Augare, H.J., Davíd-Chavez, D.M., Groenke, F.I. et al. Cult Stud of } \\
\text { Sci Educ (2017) 12: 227. https://doi.org/10.1007/s11422-015-9720-6 } \\
\text { http://informalscience.org/native-science-field-centers }\end{array}$ \\
\hline 44 & $\begin{array}{l}\text { Non Point Source Pollution Education } \\
\text { Curriculum by Wiyot Tribe, Table Bluff } \\
\text { Reservation }\end{array}$ & $\begin{array}{l}\text { Clean Water Act } \$ 319 \text { Non-Point Source Pollution Control Program } \\
\text { NON-POINT SOURCE POLLUTION EDUCATION CURRICULUM } \\
\text { Wiyot Tribe-Table Bluff Reservation } \\
\text { https://www.wiyot.us/ArchiveCenter/ViewFile/Item/55 }\end{array}$ \\
\hline 45 & $\begin{array}{l}\text { Northwest Indian Tribal College Traditional } \\
\text { Plants and Foods Program }\end{array}$ & $\begin{array}{l}\text { Includes the "13 Moons Community Garden Program" } \\
\text { http://nwicplantsandfoods.com/ }\end{array}$ \\
\hline 46 & $\begin{array}{l}\text { Qagan Tayagungin Tribe Environmental } \\
\text { Curriculum }\end{array}$ & $\begin{array}{l}\text { http://www.qttribe.org/index.asp?Type }=\text { NONE\&SEC }=\mid \text { protect } \mid \mathrm{T} 1 \backslash \\
\text { textbraceleft1BE73A61-68DD-49B9-BAB7-B6149094BFA0 } \backslash \text { protect } \backslash \\
\text { T1 \textbraceright }\end{array}$ \\
\hline 47 & $\begin{array}{l}\text { Repatriating Indigenous Technologies in an } \\
\text { Urban Indian Community }\end{array}$ & $\begin{array}{l}\text { Bang, M., Marin, A., Faber, L., Suzukovich, E.S. Urban Education. } \\
\text { (2013) 48(5): 705-733. }\end{array}$ \\
\hline 48 & Roots of Wisdom & http://omsi.edu/exhibitions/row/education-resources/ \\
\hline 49 & Since Time Immemorial & http://www.indian-ed.org/curriculum/ \\
\hline 50 & $\begin{array}{l}\text { SkyTellers: The Myths, the Macic and the } \\
\text { Mysteries of the Universe }\end{array}$ & https://www.lpi.usra.edu/education/skytellers/ \\
\hline 51 & Spokane Tribal LifeWays Curriculum & https://spokanetlc.com/ \\
\hline 52 & Tend, Gather, Grow & https://www.goodgrub.org/tend-gather-grow \\
\hline 53 & Traditions of the Sun & http://www.traditionsofthesun.org/ \\
\hline 54 & $\begin{array}{l}\text { Transdisciplinary approaches to } \\
\text { environmental science education: A Case } \\
\text { study from Northern Saskatchewan, Canada }\end{array}$ & $\begin{array}{l}\text { http://environmentalsociety.ca/programs/k-12-school-programs/ } \\
\text { water-monitoring/ }\end{array}$ \\
\hline 55 & Tribal Fisher's Handbook & $\begin{array}{l}\text { https://www.firstnations.org/wp-content/uploads/publication- } \\
\text { attachments/2013_Salmon_Marketing_Tribal_Fishers_Handbook. } \\
\text { pdf }\end{array}$ \\
\hline 56 & Turtle Island Tales & https://turtleislandtales.org/ \\
\hline 57 & $\begin{array}{l}\text { Two-World View Environmental Education } \\
\text { Project }\end{array}$ & $\begin{array}{l}\text { Johnson, Georgia Grady. 2001. Nez Perce Tribe Two-World View } \\
\text { Curriculum Teaching, Learning Environmental Education project. } \\
\text { EPA-66-951. }\end{array}$ \\
\hline
\end{tabular}




\begin{tabular}{lll}
\hline 58 & WeRNative & http://www.wernative.org/ \\
\hline 59 & Wild Foods and Medicines Resource Guide & $\begin{array}{l}\text { https: } \\
\text { //www.goodgrub.org/wild-foods/wild-foods-medicine-resources }\end{array}$ \\
\hline 60 & $\begin{array}{l}\text { Yuungnaqpiallerput The way we genuinely } \\
\text { live }\end{array}$ & http://www.yupikscience.org/ \\
\hline
\end{tabular}

\section{References}

1. Arquette, M.; Cole, M.; Cook, K.; LaFrance, B.; Peters, M.; Ransom, J.; Sargent, E.; Smoke, V.; Stairs, A. Holistic risk-based environmental decision making: A Native perspective. Environ. Health Perspect. 2002, 110, 259-264. [CrossRef] [PubMed]

2. Hoover, E.; Cook, K.; Plain, R.; Sanchez, K.; Waghiyi, V.; Miller, P.; Dufault, R.; Sislin, C.; Carpenter, D.O. Indigenous peoples of North America: Environmental exposures and reproductive justice. Environ. Health Perspect. 2012, 120, 1645-1649. [CrossRef]

3. McOliver, C.; Camper, A.; Doyle, J.; Eggers, M.; Ford, T.; Lila, M.; Berner, J.; Campbell, L.; Donatuto, J. Community-based research as a mechanism to reduce environmental health disparities in American Indian and Alaska Native communities. Int. J. Environ. Res. Public Health 2015, 12, 4076-4100. [CrossRef] [PubMed]

4. Friendship, K.A.; Furgal, C.M. The role of Indigenous knowledge in environmental health risk management in Yukon, Canada. Int. J. Circumpolar Health 2012, 71. [CrossRef] [PubMed]

5. Great Lakes Inter-Tribal, E.C. Bemidji Area: Assessment of Tribal Environmental Health Services; Center, G.L.I.-T.E., Ed.; Great Lakes Inter-Tribal Council, Inc.: Lac du Flambeau, WI, USA, 2013.

6. National Environmental Health Association. Definitions of Environmental Health. 2019. Available online: https://www.neha.org/about-neha/definitions-environmental-health (accessed on 23 October 2019).

7. Cajete, G. Native Science: Natural Laws of Interdependence; Clear Light Publishing: Santa Fe, NM, USA, 2000.

8. Demssie, Y.N.; Biemans, H.J.; Wesselink, R.; Mulder, M. Combining Indigenous Knowledge and Modern Education to Foster Sustainability Competencies: Towards a Set of Learning Design Principles. Sustainability 2020, 12, 6823. [CrossRef]

9. Medin, D.L.; Bang, M. The Cultural Side of Science Communication. Proc. Natl. Acad. Sci. USA 2014, 111, 13621-13626. [CrossRef] [PubMed]

10. Arenas, A.; Reyes, I.; Wyman, L. When indigenous and modern education collide. World Stud. Educ. 2007, 8, 33-64. [CrossRef]

11. The Qagan Tayagungin Tribe Environmental Department. Environmental Curriculum 2012; The Qagan Tayagungin Tribe Environmental Department: Sandpoint, ID, USA, 2012.

12. Ward, T.J.; Vanek, D.; Marra, N.; Holian, A.; Adams, E.; Jones, D.; Knuth, R. The Big Sky Model: A Regional Collaboration for Participatory Research on Environmental Health in the Rural West. J. High. Educ. Outreach Engagem. 2008, 12, 103-114.

13. Wiyot Tribe, E.D.; Non-Point Source Pollution Education Curriculum. Wiyot Tribe Environmental Department. 2010. Available online: http://www.wiyot.us/sites/default/files/u6/NPS\%20Education\%20Curriculum.pdf (accessed on 26 October 2020).

14. Hoover, E. Cultural and health implications of fish advisories in a Native American community. Ecol. Process. 2013, 2, 4. [CrossRef]

15. O'Neill, C. Fishable Waters. Am. Indian Law J. 2013, 1, 13-21.

16. Donatuto, J.; Satterfield, T.A.; Gregory, R. Poisoning the body to nourish the soul: Prioritizing health risks and impacts in a Native American community. Health Risk Soc. 2011, 13, 103-127. [CrossRef]

17. Donatuto, J.; Campbell, L.; Gregory, R. Developing responsive indicators of Indigenous community health. Int. J. Environ. Res. Public Health 2016, 13, 899. [CrossRef] [PubMed]

18. Donatuto, J.; Campbell, L.; Trousdale, W. The 'value' of values-driven data in identifying Indigenous health and climate change priorities. Clim. Chang. 2019, 158, 161-180. [CrossRef]

19. Garibaldi, A.; Turner, N. Cultural Keystone Species: Implications for Ecological Conservation and Restoration. Ecol. Soc. 2004, 9, 9. [CrossRef]

20. Gonzalez, N.; Moll, L.C.; Amanti, C. (Eds.) Funds of Knowledge: Theorizing Practices in Households, Communities and Classrooms; Lawrence Erlbaum Associates: Mahwah, NJ, USA, 2005. 
21. Ball, J. As if Indigenous knowledge and communities mattered: Transformative education in First Nations communities in Canada. Am. Indian Q. 2004, 28, 454-479. [CrossRef]

22. Bang, M.; Medin, D. Cultural Processes in Science Education: Supporting the Navigation of Multiple Epistemologies. Sci. Educ. 2010, 94, 1008-1026. [CrossRef]

23. Beaulieu, D. A Survey and Assessment of Culturally Based Education Programs for Native American Students in the United States. J. Am. Indian Educ. 2006, 45, 50-61.

24. Klug, B.J.; Whitfield, P.T. Widening the Circle: Culturally Relevant Pedagogy for American Indian Children; Routledge Falmer: New York, NY, USA, 2002.

25. Pewewardy, C. Learning styles of American Indian/Alaska Native students: A review of the literature and implications for practice. J. Am. Indian Educ. 2002, 41, 22-56.

26. Demmert, W.C., Jr.; Towner, J.C. A Review of the Research Literature on the Influences of Culturally Based Education on the Academic Performance of Native American Students; Final Paper. 2003. Available online: https://educationnorthwest.org/sites/default/files/cbe.pdf (accessed on 23 October 2020).

27. Reyhner, J.; Gilbert, W.S.; Lockard, L. (Eds.) Honoring Our Heritage: Culturally Appropriate Approaches for Teaching Indigenous Students; Northern Arizona University: Flagstaff, AZ, USA, 2011; pp. 43-55.

28. Falk, J.H.; Storksdieck, M.; Dierking, L.D. Investigating public science interest and understanding: Evidence for the importance of free-choice learning. Public Underst. Sci. 2007, 16, 455-469. [CrossRef]

29. Kana 'iaupuni, S.M. Ka 'akālai Kū Kanaka: A call for strengths-based approaches from a Native Hawaiian perspective. Educ. Res. 2005, 34, 32-38. [CrossRef]

30. Lee, A.S.; Wilson, W.; Tibbetts, J.; Gawboy, C.; Meyer, A.; Buck, W.; Knutson-Kolodzne, J.; Pantalony, D. Celestial calendar-paintings and culture-based digital storytelling: Cross-cultural, interdisciplinary, STEM/STEAM resources for authentic astronomy education engagement. EPJ Web Conf. 2019, 200, 01002. [CrossRef]

31. Indian Land Tenure Foundation. Lessons of Our Land. 2014. Available online: http://www.lessonsofourland. org/ (accessed on 13 October 2014).

32. Tribe, Y. Yuungnaqpiallerput: The Way We Genuinely Live. Masterworks of Yupik Science and Survival 2008. Available online: http://www.yupikscience.org/ (accessed on 23 July 2018).

33. Swinomish Indian Tribal Community. 13 Moons: The 13 Lunar Phases, and how they Guide the Swinomish People; Office of Planning \& Community Development: Seattle, WA, USA, 2006.

34. Stein, J.; Valdez, S.; Maryboy, N. Swinomish Indian Tribal Community: Developing an Informal Environmental Health Education Model. Summative Evaluation Report. Center for Advancement of Informal Science Education (CAISE). 2017. Available online: https://www.informalscience.org/sites/default/files/SITC_NSF\%20Pathways_Final\% 20Evaluation\%20Report_022818.pdf (accessed on 26 October 2020).

35. Brega, A.G.; Ang, A.; Vega, W.; Jiang, L.; Beals, J.; Mitchell, C.M.; Moore, K.; Manson, S.M.; Acton, K.J.; Roubideaux, Y. Mechanisms underlying the relationship between health literacy and glycemic control in American Indians and Alaska Natives. Patient Educ. Couns. 2012, 88, 61-68. [CrossRef] [PubMed]

36. Call, K.T.; McAlpine, D.D.; Johnson, P.J.; Beebe, T.J.; McRae, J.A.; Song, Y. Barriers to care among American Indians in public health care programs. Med. Care 2006, 44, 595-600. [CrossRef] [PubMed]

37. Singleton, K.; Krause, E. Understanding Cultural and Linguistic Barriers to Health Literacy. Ky. Nurse 2010, 58,14 .

38. Smylie, J.; Williams, L.; Cooper, N. Culture-based literacy and Aboriginal health. Can. J. Public Health 2006, 97 (Suppl 2), S21-S25.

39. Tripp-Reimer, T.; Choi, E.; Kelley, L.S.; Enslein, J.C. Cultural Barriers to Care: Inverting the Problem. Diabetes Spectr. 2001, 14, 13-22. [CrossRef]

40. Bang, M.; Medin, D.L.; Atran, S. Cultural mosaics and mental models of nature. Proc. Natl. Acad. Sci. USA 2007, 104, 13868-13874. [CrossRef]

41. Ladson-Billings, G. The Dreamkeepers: Successful Teaching for African-American Students; Jossey-Bass: San Francisco, CA, USA, 1994.

42. Ladson-Billings, G. Toward a Theory of Culturally Relevant Pedagogy. Am. Educ. Res. J. 1995, 32, $465-491$. [CrossRef]

43. Ladson-Billings, G. But that's just good teaching! The case for culturally relevant pedagogy. Theory Pract. 1995, 34, 159-165. [CrossRef] 
44. Donatuto, J. When Seafood Feeds the Spirit Yet Poisons the Body: Developing Health Indicators for Risk. Assessment in a Native American Fishing Community. Ph.D. Thesis, University of British Columbia, Vancouver, BC, Canada, 2008.

Publisher's Note: MDPI stays neutral with regard to jurisdictional claims in published maps and institutional affiliations.

(C) 2020 by the authors. Licensee MDPI, Basel, Switzerland. This article is an open access article distributed under the terms and conditions of the Creative Commons Attribution (CC BY) license (http://creativecommons.org/licenses/by/4.0/). 